Ziemia Lubuska. Dziedzictwo kulturowe i tożsamość regionu $w$ perspektywie powojennego siedemdziesięciolecia, red. Tomasz Nodzyński, Marceli Tureczek, Polskie Towarzystwo Historyczne Oddział w Zielonej Górze, Zielona Góra-Gorzów Wielkopolski 2015, ss. 398

\title{
MARCIN TUJDOWSKI
}

Instytut Zachodni im. Zygmunta Wojciechowskiego w Poznaniu

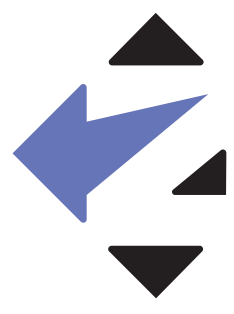


Omawiana pozycja została wydana nakładem Polskiego Towarzystwa Historycznego (Oddział w Zielonej Górze). Treść została podzielona na trzy części. W pierwszej zgrupowano artykuły poświęcone zagadnieniu dziedzictwa materialnego omawianego regionu. Druga część, zatytułowana Kreowanie tożsamości wokół dziedzictwa, jest w moim przekonaniu najbardziej interesująca, ponieważ dotyka kwestii regionalizmu nowej Ziemi Lubuskiej w odniesieniu do tożsamości jej mieszkańców, czyli dotyczy kwestii pomostu między historią a teraźniejszością. W części trzeciej Ziemi Lubuskiej znajdziemy teksty dotyczące - jak zatytułowano - Powojennego życia społecznego i kulturalnego. Z racji tego, że Ziemia Lubuska jest pracą obszerną pod względem zarówno treści, jak i poruszanych zagadnień, skupię się na wybranych tekstach.

Od razu nasuwa się pewna wątpliwość co do autonomiczności treści części drugiej i trzeciej. Przyporządkowanie do części trzeciej tekstów opisujących pewne historyczne i zamknięte zdarzenia nie budzi wątpliwości. Dlatego pasują tam takie opracowania, jak Mniejszość ukraińska na Ziemi Lubuskiej w latach 1956-2014 Bohdana Halczaka czy Gorzowska babokracja, czyli kobiety w rozwoju kulturalnym miasta Gorzowa Wlkp. w latach 1945-1968 Natalii Gorzkiewicz. Natomiast znajdziemy tam również ważne teksty jako żywo dotyczące właśnie kwestii budowy tożsamości lokalnej w oparciu o dziedzictwo materialne, zdecydowanie bardziej pasujące do drugiej części. Chodzi o artykuły autorstwa Leszka Kani (Sztuka współczesna w Muzeum Ziemi Lubuskiej w Zielonej Górze jako element kształtowania tożsamości regionalnej), Arkadiusza Cincio (Gromadzenie i prezentacja niemieckiego dziedzictwa kulturowego przez Muzeum Ziemi Lubuskiej w Zielonej Górze) czy Anitty Maksymowicz (Fragmenty lustra - trzy planowane wystawy stałe $w$ zielonogórskim Muzeum jako odbicie lubuskiej tożsamości).

Wielokrotnie w regionie lubuskim (a czasem i poza nim) można spotkać się z wypowiadanymi z pewnym żalem opiniami o niskiej atrakcyjności historycznej i turystycznej regionu. We wprowadzającym artykule Zniszczenia miast Ziemi Lubuskiej w 1945 roku i ich konsekwencje dla współczesnych przestrzeni miejskich Barbara Bielinis-Kopeć (pełniąca funkcję Lubuskiego Wojewódzkiego Konserwatora Zabytków) rzetelnie wyjaśnia, dlaczego tak się stało. Zabytkowe miasta tego regionu wyjątkowo ucierpiały w wyniku walk w 1945 r. Szczególnymi przypadkami były miasta frontowe, ze starówkami pełnymi zabytków, takie jak Kostrzyn nad Odrą (zniszczony w 95\%), Gubin (90\%), Dobiegniew (80\%), Strzelce Krajeńskie (85\%) itd. Zniszczono 79\% zakładów przemysłowych. Akcja zbierania cegieł dla odbudowania miejscowości w Polsce centralnej (a przede wszystkim Warszawy) oraz szabrownictwo w latach późniejszych dopełniły dzieła zniszczenia.

Artykuł Krzysztofa Wasilewskiego (Przemiany pamięci zbiorowej na Ziemi Lubuskiej) stanowi znakomity wstęp do części drugiej książki. Autor w niezwykle skondensowanej formie przyjrzał się rozwojowi pamięci zbiorowej na Ziemi Lubuskiej w pewnych przedziałach czasu (okres powojenny; po roku 1956; po transformacji ustrojowej). Po lekturze tekstu można mieć wątpliwości, czy wybór roku 1956 jako cezury zmian pamięci zbiorowej jest słuszny. Autor sam wskazuje, że w tym okresie nie było jakichś znacznych zmian tej pamięci (s. 171), dodatkowo w tej części odwołuje się do wydarzeń sprzed 1956 r. (powstanie NRD i układ zgorzelecki). 
Wasilewski sam zauważa nieco dalej, że większe zmiany zaszły po 1970 r., tj. po podpisaniu przez rząd PRL układu granicznego z RFN. Tutaj kolejna uwaga. Pewne zastrzeżenia budzi pogląd autora, że po 1989 r. zrezygnowano z określenia „Ziemie Odzyskane" (s. 173). Otóż nastąpiło to znacznie wcześniej. Odwrót od tego zwyczajowego określenia zaobserwowano właśnie po 1970 r., tzn. po likwidacji Towarzystwa Rozwoju Ziem Zachodnich. Natomiast słusznie Wasilewski wychwycił zmianę propagandowego wektora, tj. zwrot w kierunku gloryfikacji poniemieckiej przeszłości Ziem Zachodnich odwzorowany w lokalnej prasie. Tekst Krzysztofa Wasilewskiego po rozbudowaniu i poszerzeniu bazy źródłowej (aby wyjść poza szczupłe ramy kilku wywiadów i artykułów w prasie lokalnej) byłby dobrym syntezującym zwornikiem dla treści całej omawianej tu książki.

Opublikowany pod wiele obiecującym tytułem artykuł Olgierda Kieca Pęknięta tożsamość. Ziemia Lubuska pomiędzy historycznymi tradycjami Ślq̨ska i Nowej Marchii nie rozczarowuje. Autor wnikliwie i rzetelnie odtworzył historyczne próby wytworzenia spójnej tożsamości regionalnej na terenie dzisiejszej Ziemi Lubuskiej. Olgierd Kiec nie zapomniał o przedwojennych problemach $\mathrm{z}$ wydzieleniem jednego regionu na obszarze rejencji frankfurckiej i Marchii Granicznej. Warto nieco uzupełnić wywód autora na temat powojennych perypetii związanych z tworzeniem określenia Ziemia Lubuska. Zwrócił on uwagę na mało sensowne włączenie Piły do regionu lubuskiego przez naukowców z Instytutu Zachodniego po $1945 \mathrm{r}$. Jednak wypada przypomnieć, że nieco wcześniej (w 1945 r.) powołano kościelną Administrację Apostolską Kamieńską, Lubuską i Prałatury Pilskiej (pełna nazwa). Po prostu nie było $\mathrm{w}$ tamtym regionie jednego, dominującego centralnego ośrodka miejskiego, który mógłby skupić w sobie funkcje quasi-stołeczne.

Grzegorz Biszczanik przyjrzał się kartom pocztowym wydawanych zaraz po wojnie (Ziemia Lubuska w ikonografii dawnych kart pocztowych pierwszej powojennej dekady). W przeszłości wrocławski kulturoznawca profesor Piotr Banaś przekonał nas o wadze tego zagadnienia w badaniu kształtowania się tożsamości Ziem Zachodnich. Autor zajął się zagadnieniem, które wymaga zbadania dużej liczby tropów. Warto uzupełnić jego wywód. Przede wszystkim zarówno w biogramie Jana Bułhaka (s. 183, przypis 49), jak i w tekście zabrakło informacji ważnej w kontekście omawianej tematyki, mianowicie, że ten wybitny polski fotograf był zatrudniony przez poznański Instytut Zachodni do prowadzenia fotograficznej dokumentacji Ziem Zachodnich. Autor wspomniał o pocztówkach wydawanych przez Instytut Zachodni; można dodać, że prezentowały one nie tylko Ziemie Zachodnie, ale także np. łużycki Budziszyn czy kościół we Frankfurcie nad Odrą, który został opisany jako polskie Słubice. Do tego uwaga odnośnie do brzmienia nazw miejscowości (s. 181) niestety, autor nie spostrzegł, że nie chodzi o polskie (czy polonizowane) nazwy, ale o historycznie wykształcone nazwy w języku dolnołużyckim, czasem przytaczane w spolszczonej wymowie (np. Zemsz czy Przybrzeg). To nie efekt polskiej propagandy, ale uznanie historycznego i kulturowego faktu obecności narodu Serbołużyczan na tym obszarze.

Tekst autorstwa Przemysława Słowińskiego (Miejsca pamięci narodowej zwiqzane z II wojnq światowq na terenie województwa lubuskiego) dotyczy ważnej i, jak 
się wydaje, zapomnianej ostatnimi laty kwestii miejsc związanych z martyrologią. Zrządzeniem historii na terenie dzisiejszego województwa lubuskiego znajdują się liczne i ważne punkty z mapy wojennej martyrologii. Autor wylicza w sumie 156 miejsc pamięci na Ziemi Lubuskiej o różnym charakterze (pomniki, cmentarze, miejsca kaźni itp). Na szczególną uwagę zasługują obozy. W przygranicznych Gębicach mieścił się Stalag III B Amtitz, obóz, w którym internowano m.in. zakonników z Niepokalanowa z ojcem Maksymilianem Kolbe. W Obrzycach pod Międzyrzeczem w szpitalu dla psychicznie i nerwowo chorych w ramach Akcji T4 Niemcy zamordowali ok. 10 tys. osób uznanych za jednostki niepełnowartościowe. W Słońsku w 1933 r. władze pruskie założyły Konzentrationslager Sonnenburg, pierwszy taki obiekt w Niemczech, będący pierwowzorem późniejszych obozów koncentracyjnych. W Żaganiu mieścił się słynny Stalag Luft III, obóz dla alianckich pilotów. Z kolei nieopodal Dobiegniewa działał Oflag II C Woldenberg, obóz dla oficerów Wojska Polskiego. Autor dyskretnie przypomina, nie rozwijając tego wątku, że niektóre ze wspomnianych obiektów są obecnie zdane wyłącznie na środki samorządowe. Zatem należy dodać (o czym Przemysław Słowiński nie pisze wprost), że skandalem jest, że np. muzeum Stalagu w Żaganiu (a więc obiekt, który ze względu na anglosaskich lotników i wielką ucieczkę zapisał się w światowej historii i kulturze masowej) musi za pośrednictwem strony internetowej błagać o wsparcie i datki na konserwację i bieżące remonty, których nie jest w stanie zapewnić gmina. Z własnej praktyki badawczej dodam smutny fakt, że placówka muzealna w Dobiegniewie znacząco ucierpiała finansowo z powodu uwikłania jej w bieżący spór polityczny.

Wątek miejsc pamięci znalazł kontynuację $\mathrm{w}$ krótkim komunikacie $\mathrm{z}$ badań autorstwa Joanny Kasprowicz (Pomniki pamięci o ofiarach hitleryzmu na Ziemi Lubuskiej w świadomości młodzieży wybranych miejscowości). Autorka podjęła trud przeprowadzenia socjologicznych badań ankietowych $\mathrm{w}$ dziesięciu miejscowościach, w których znajdują się miejsca pamięci. Badaniami objęto młodzież z lokalnych szkół gimnazjalnych i ponadgimnazjalnych. Niestety, wnioski nie napawają optymizmem. Młodzi respondenci wykazali się stosunkowo niewielką wiedzą i świadomością o miejscach pamięci w ich miejscowościach. Badania Joanny Kasprowicz wykazały luki do nadrobienia w zakresie zarówno godzin lekcyjnych poświęconych lokalnej historii, jak i zaopatrzenia szkół w literaturę o takiej tematyce.

Marta Jadwiga Bąkiewicz postrzega zagadnienie miejsc pamięci w zupełnie innym duchu (Kulturowo-historyczny krajobraz Nadodrza w kręgu odpominań). Autorka już w tytule odwołuje się do kategorii odpominania spopularyzowanej przez prof. Huberta Orłowskiego, wieloletniego pracownika Instytutu Zachodniego w Poznaniu. Przy czym wraca do nierozwiązywalnej i, moim zdaniem, fałszywej antynomii każącej mieszkańcom Ziem Zachodnich wybierać między kultywowaniem ogólnopolskiej pamięci historycznej a pamięcią danego miejsca, co zazwyczaj oznacza konieczność przyjęcia niemieckiego genius loci. Upraszczając nieco wywody autorki, trudno chyba przypuszczać, aby współcześni mieszkańcy Ziem Zachodnich zaangażowali się emocjonalnie $\mathrm{w}$ kultywowanie tradycji pruskich, dziewiętnastowiecznych dworków literackich z epoki romantyzmu funkcjonujących ongiś na obszarze Ziemi Lubuskiej. 
Niestety, Ziemia Lubuska powiela mankamenty podobnych publikacji. Zawiera wiele szczegółowych, wycinkowych tekstów, natomiast brakuje tekstu-klamry (wstęp od redakcji nie może pełnić takiej funkcji). U niektórych autorów widać miszmasz w etymologii definicji dotyczących przeszłości Ziem Zachodnich i doborze źródeł oraz towarzyszący temu rys ideologiczny w podejściu do pogranicza polsko-niemieckiego. W niektórych tekstach ujawnia się nieumiejętność oddzielenia źródeł informacji pierwotnych od wtórnych (skutek braku oczytania w literaturze przedmiotu), warto zatem, na przykład, pamiętać, że nie każdy, kto wspomni o jakimś chwytliwym postnaukowym terminie, jest tego terminu autorem.

Innym wspólnym (niestety!) mianownikiem tekstów zamieszczonych w omawianej książce, poświęconych przecież dziedzictwu kulturowemu regionu, jest niezwykle słabo wyeksponowane dziedzictwo kulturowe Serbołużyczan na tych ziemiach. Był to żywioł niewątpliwie słabszy niż żywioł polski i niemiecki, ale jednak Serbowie zaznaczyli się w krajobrazie kulturowym i materialnym regionu. Na przykład Aleksandra Ibragimow (Pamięć, integracja i dziedzictwo kulturowe - studium przypadku na przykładzie granicznego odcinka rzeki Odry) zauważyła, iż „Nadodrze było miejscem przenikania się wielu wpływów politycznych, narodowych oraz kulturowych" (s. 284), dostrzega nawet wpływy szwedzkie, natomiast ani słowa o barwnej grupie Serbów Odrzańskich (niem. Oderwenden), posługującej się własnym dialektem i wyróżniającej się barwnymi strojami w okolicach Słubic, Krosna Odrzańskiego i Cybinki aż do lat 30. ubiegłego wieku. Dotyczy to również tekstów opisujących rozważania nad kulturowym regionalizmem (Ziemia Lubuska vs. Śląsk Lubuski). Jest to wątek o tyle ważny, że w pewnych okresach historii żywioł serbołużycki z Nadodrza stykał się bezpośrednio z żywiołem polskim, zachowując pochodzącą z czasów plemiennych słowiańską ciągłość, czego zaskakującym efektem był np. wpływ języka Łużyczan na gwarę zachodniej Wielkopolski (fenomen opisany przez wybitną językoznawczynię prof. Monikę Gruchmanową z Poznania). To rzadkie zjawisko kulturowe miało miejsce jeszcze w XVII w. właśnie na terenie będącym przedmiotem refleksji omawianej Ziemi Lubuskiej i rzuca nieco inne światło na kwestię celowości np. propagandy o ziemiach słowiańskich czy powrocie do Macierzy.

Natomiast należy docenić różnorodność ujęć tych samych zagadnień - np. kwestii rozwoju i pielęgnowania tożsamości regionalnej. Wynika to w znacznej mierze z doboru autorów, których znaczna część znakomicie odnalazła się w tematyce tomu i może poszczycić się dorobkiem z zakresu poruszanej tam tematyki. Cieszy również fakt, że nowy regionalizm i kwestia budowy tożsamości mieszkańców Środkowego Nadodrza nadal budzi takie zainteresowanie tylu badaczy. 